\title{
Komunikacja marketingowa producentów napojów alkoholowych wysokoprocentowych w Polsce
}

\author{
Marketing communication of high-proof alcoholic \\ beverages producers in Poland
}

\author{
mgr Małgorzata Szafranowicz \\ Szkoła Główna Handlowa w Warszawie, doktorantka w Katedrze Rynku, Marketingu i Jakości \\ ORCID: 0000-0002-8624-9813 \\ e-mail:ms75645@doktorant.sgh.waw.pl
}

\begin{abstract}
W publikacji dokonano przeglądu definicji komunikacji marketingowej, jej narzędzi i kanałów oraz zaprezentowano działania producentów alkoholi wysokoprocentowych w zakresie komunikacji marketingowej na rynku polskim. Problem badawczy niniejszego artykułu to odpowiedź na pytanie, w jaki sposób producenci napojów alkoholowych wysokoprocentowych komunikują się ze swoimi konsumentami w warunkach znacznego ograniczenia ich działalności w sferze marketingu, w tym całkowitego zakazu reklamy publicznej. Publikacja ma charakter przeglądowo-poznawczy. Część teoretyczna powstała $\mathrm{z}$ wykorzystaniem analizy literatury przedmiotu i danych zastanych. Przegląd działań producentów alkoholi wysokoprocentowych w zakresie komunikacji marketingowej na rynku polskim stanowi część poznawczą opracowania.
\end{abstract}

Keywords

komunikacja marketingowa, uwarunkowania prawne, alkohole wysokoprocentowe

The publication reviews the definition of marketing communication, its tools and channels, and presents the activities of high-proof alcoholic beverages producers in the field of marketing communication on the Polish market. The research problem of this article is the answer to the question: how do producers of high-proof alcoholic beverages communicate with their consumers in the conditions of a significant restrictions in their marketing activities (including a total ban on public advertising). The publication is of overview and cognitive nature. The theoretical part was created using the literature analysis of the subject and the existing data. The review of the activities of hard alcohol producers in the field of marketing communication on the Polish market is a cognitive part of the study.

Slowa kluczowe

marketing communication, legal determinants, high-proof alcoholic beverages

Str. $28-40$

\section{Bibliografia}

Chmielarz, W. (red.). (2016). Mobilne aspekty technologii informacyjnych. Warszawa: Wyd. Naukowe Wydziału Zarządzania Uniwersytetu Warszawskiego. https://doi.org/10.7172/978-83-65402-25-7.2016.wwz.7

Dorenda-Zaborowicz, M. (2012). Marketing w social media. Nowe Media. Studia i Rozprawy, (3), 59-79. https://doi.org/ $10.12775 / \mathrm{nm} .2012 .003$ 
Garbarski, L. (red.). (2011). Marketing. Kluczowe pojęcia i praktyczne zastosowania. Warszawa: PWE.

IAB Polska. (2018). Raport Strategiczny Internet 2017/2018. Warszawa: IAB Polska.

Konstytucja Rzeczypospolitej Polskiej z dnia 2 kwietnia 1997 r. DzU z 1997 r. nr 78 poz. 483.

Kotler, P. i Keller, K. L. (2016). A Framework for Marketing Management. Global Edition, England: Pearson Education.

Kotler, P., Kartajaya, H. i Setiawan, I. (2010). Marketing 3.0. Dobry produkt? Zadowolony klient? Spetniony czlowiek! Warszawa: MT Biznes.

Liczmańska, K. (2011). Promocja konsumencka w warunkach zakazu reklamy publicznej. Acta Universitatis Nicolai Copernici, Zarzadzanie, XXXVIII (404), 91-102. https://doi.org/10.12775/aunc_zarz.2011.007

Liczmańska, K. (2013). Social media jako przestrzeń komunikacji z klientem w branży alkoholi wysokoprocentowych. Polityki Europejskie, Finanse i Marketing, 9(58), 279-287.

Liczmańska, K. i Wiśniewska, A. M. (2011). Wykorzystanie postaci jako instrumentu perswazji w reklamie. Bydgoszcz: Wyd. Kujawsko-Pomorskiej Szkoły Wyższej w Bydgoszczy.

Mruk, H., Pilarczyk, B. i Sławińska, M. (2015). Marketing. Koncepcje - Strategie - Trendy. Poznań: Wyd. Uniwersytetu Ekonomicznego w Poznaniu.

Naczelny Sąd Administracyjny, wyrok II GSK 982/17 z dnia 13 lipca 2017 r.

Nowacki, F. (2014). Marketing 4.0 - nowa koncepcja w obliczu przemian współczesnego konsumenta. Marketing i Rynek, (6), 11-19.

Sadowska, E. (2013). Komunikacja marketingowa: współczesne wyzwania i kierunki rozwoju. Studia Ekonomiczne. Uniwersytet Ekonomiczny w Katowicach, 140(13), 122-131.

Taranko, T. (2015a). Komunikacja marketingowa. Istota, uwarunkowania, efekty. Warszawa: Wolters Kluwer.

Taranko, T. (red.). (2015b). Działania marketingowe i ich uregulowania w Polsce. Warszawa: Wolters Kluwer.

Ustawa z dnia 26 października 1982 r. o wychowaniu w trzeźwości i przeciwdziałaniu alkoholizmowi. DzU z 1982 r. nr 35 poz. 230 .

Ustawa z dnia 26 stycznia 1984 r. Prawo prasowe. DzU z 1984 r. nr 5 poz. 24.

Ustawa z dnia 29 grudnia 1992 r. o radiofonii i telewizji. DzU z 1993 r. nr 7 poz. 34.

Ustawa z dnia 16 kwietnia 1993 r. o zwalczaniu nieuczciwej konkurencji. DzU z 1993 r. nr 47 poz. 211.

Ustawa z dnia 23 sierpnia 2007 r. o przeciwdziałaniu nieuczciwym praktykom rynkowym. DzU z 2007 r. nr 171 poz. 1206.

Ustawa z dnia 6 grudnia 2008 r. o podatku akcyzowym. DzU z 2009 r. nr 3 poz. 11.

Ustawa z dnia 7 maja 2009 r. o towarach paczkowanych. DzU z 2009 r. nr 91 poz. 740.

Ustawa z dnia 10 maja 2018 r. o ochronie danych osobowych. DzU z 2018 r. poz. 1000.

Wiktor, J. W. (2013). Komunikacja marketingowa: modele, struktury, formy przekazu. Warszawa: Wyd. Naukowe PWN. https://doi.org/10.7206/mba.ce.2084-3356.113

Wrzosek, W. (red.). (2012). Strategie marketingowe. Warszawa: PWE. 